\title{
Dietary intake of micronutrient and Basal Metabolic Index of women in rural Pakistan
}

\author{
MUHAMMAD ISRAR ${ }^{1, \boldsymbol{v}}$, SALEEM KHAN $^{2}$, AURANGZEB $^{3}$, ABID ALI $^{4}$ \\ ${ }^{1}$ Pakistan Science Foundation. Constitution Ave, Islamabad, Pakistan. Tel.: +92-51-9202469, `email: israr.abbas@gmail.com \\ ${ }^{2}$ Department of Human Nutrition, University of Agriculture. Peshawar-25130, Khyber Pakhtunkhwa, Pakistan \\ ${ }^{3}$ Nuclear Institute for Food and Agriculture. Peshawar, Khyber Pakhtunkhwa, Pakistan \\ ${ }^{4}$ Department of Zoology, Abdul Wali Khan University. Mardan 23200, Khyber Pakhtunkhwa, Pakistan.
}

Manuscript received: 16 September 2017. Revision accepted: 29 November 2017.

\begin{abstract}
Setyawan. 2017. Dietary intake of micronutrient and Basal Metabolic Index (BMI) of women in rural Pakistan. Nusantara Bioscience 9: 396-402. Population's consumption of essential nutrients and defense against diseases is best indicated by the nutritional status of the individual. Asian women as the central player of the family and, therefore, they propagate the ill effects of malnutrition to generation. In this study, nutritional status and micronutrients (dietary minerals and vitamins) intake of rural women in Pakistan were investigated. One district of Khyber Pakhtunkhwa was selected, out of which, three villages were selected. From each village, 50 rural women were selected for the study. Information about food intake was obtained by a questionnaire. Nutrients intake was obtained from details of food intake in questionnaire, namely, $523 \mathrm{mg} /$ day of calcium; $773 \mathrm{mg} / \mathrm{day}$ of phosphorus; $28 \mathrm{mg} / \mathrm{day}$ of Iron; $11 \mathrm{mg} / \mathrm{day}$ of zinc; $6.61 \mathrm{mg} /$ day of Iodine; 172 R.E./day of Vitamin-A; $21 \mathrm{mg} /$ day of Vitamin-C; $2.79 \mathrm{mg} /$ day of Niacin; $0.31 \mathrm{mg} /$ day of Thiamine; $0.32 \mathrm{mg} /$ day of Riboflavin. The Basal Metabolic Index (BMI) was observed between 19.6 and 52.2 with a mean of 28.54. The study concluded that women's proportion on consuming mineral and vitamins according to RDA was very small, similarly, the proportion of women in a normal range of BMI was also very small and the curve for BMI suddenly changes direction to the right which confirms that the overweight and obese rural women population was quite common.
\end{abstract}

Keywords: Micronutrient status, rural women, Basal Metabolic Index, Pakistan

\section{INTRODUCTION}

Undernutrition is a failure of a person to consume sufficient essential nutrient for prolonged period depriving him of basic requirements which makes his body vulnerable to diseases and retards his growth and development. There are many factors which have been identified as contributors to malnutrition. One of them is the inability of food utilization containing protein, fruit, vegetables, and liquids. Similarly, there are different drugs which have been found associated with loss of hunger (Ruiz-Lopez et al. 2003). Malnutrition is linked to the prevalence of diseases, and weak stature affecting physical and mental labor capability, and repeated times hospitalization (Arellano et al. 2004)

It is poverty that is linked to malnutrition making it the world's major nutritional problem. Malnutrition has been observed in many groups including social groups, age groups, ethnic groups and gender groups (Rouse 2003) and has been found as the greatest problem. It has been identified as a major determinant of health causing a very damaging yet important outcome in the form of illness. Higher female mortality has been caused by various social factors including differential treatment among the girls and boys towards food accessibility. Similar is the case with the healthcare. Malnutrition with its manifestations is accelerated when the society discriminate in the resources of house-hold for allocation for them. A balanced diet has been mentioned as a basic challenge faced by the women of third world countries, especially the rural women (Martorell et al. 1998; Tabak et al. 2000). Good health can easily be maintained by intake of proper and sufficient diet and it is the improper and insufficient food intake that is the leading cause of development of many nutritional problems like weight gain, heart problems and diabetes, which as a result spoils individual's life quality (Pirlich and Lochs 2001; Peel et al. 2005).

It is women that propagate the effects of malnutrition by giving birth to low birth weight baby (LBW) with increased susceptibility to early mortality and diseased conditions. The rural women face multiple challenges while playing their role in economic, biological, and social fields. They are placed in the secondary position throughout their life and especially when it comes to nutrition and food accessibility leading to the compromise on their childcare efficiency and processing plus preparation of food. The case is worsened when the women are designated to preschooler and infants feeding. In many rural families, the women play a role in economic and it makes them to stay away from household and incompatible with the care of the child.

The modern economic activity has allowed enhanced involvement of women for family support (Pirlich and Lochs 2001; Peel et al. 2005). Rural women’s economic role has been negatively affecting her own as well as her children's health. A significant role of women informalsector employment has been found playing very significant role rural areas and the salutation is worsening in countries 
like Pakistan. The outcome of pregnancy is adversely influenced by extensity of physical activity and workload leading to harming of the fetus as manifested in several ways. Similar is the effect of stress alongside fatigue and disturbed nutrition over the pregnancy outcomes.

All over the world, a $2.5 \mathrm{~kg}$ weight at the time of birth prevails in infants for up to almost 20 million infants which constitutes a $17.6 \%$ of worldwide births in third world countries. In developing countries, mother's malnutrition results in growth retardation of intrauterine leading to almost $80 \%$ of birth low weights LBW and resultantly these infants have to suffer the fatal consequences of mother's malnutrition as the rate of growth reduction, development and survival.

The above-detailed discussion has made it clear that mother's good nutrition is a lifelines towards the healthy growth of children and infants where the good nutrition of infants warrants delicate attention regarding the achievement of global health standards. Knowledge of the nutrient intake leads to the nutrition information of the subject and that is the reason we planned this study to know the micronutrient intake of rural mothers belonging to District of Nowshera of the province of Khyber Pakhtunkhwa, Pakistan using dietary recall questionnaire.

\section{MATERIALS AND METHODS}

The method of 24 hours memory recall questionnaire was used to record the micronutrient and food intake of rural women. Women from three villages namely Kheshki, Pir sabaq and Akora Khattak of the District of Nowshera, the Province of Khyber Pakhtunkhwa, Pakistan were selected,moreover the villages were located at the angles of a triangle making it possible as the sample for the whole district. The variations in food habits and culture inside a district were equally considered.

\section{Memory recall questionnaire method}

Dietary intake and personal history information from fifty (50) rural women of the three villages which were selected in Nowshera (Kheshki, Akora Khattak and Pir Sabak). Using 24-hour recall questionnaire method, three alternate days were selected for data recording during a single week. Variations in cultural, geographical and social considerations were covered by the study. On a volunteer basis, selection of fifty rural women was made from every village. Questionnaire was filled through educated women of each village. She was also designated for data taking, contacts and interface. Training about methodology and objectives of the study was conducted to the women who were responsible for data taking etc. Datasheets were prepared by recording responses to questions of rural women regarding food intake during 24 hours. Calculation of micronutrient intake, dietary mineral and vitamin, was done using excel spreadsheet which was earlier developed by the Department of Nutrition, Food Science Division, Nuclear Institute for Food and Agriculture (NIFA), Peshawar, Pakistan.

\section{Data presentation and statistical analysis}

Appendices are representing an intake of micronutrients and food data of rural women of the three villages and the results chapter comprises of the statistics and tables of the three villages along with combined results. Frequency distribution of the obtained results was prepared and RDA table, for comparison reason, was also given in Appendix.

\section{RESULTS AND DISCUSSION}

\section{Nutrients intake of women \\ Akora Khattak}

Recommended Dietary Allowances (RDA) for women was used as a reference in calculating group level of the mean daily intake of vitamin and dietary mineral. 24-hour memory recall questionnaire method was used to investigate daily intake of micronutrient of 150 rural women leading to the calculation of daily intake of micronutrient (vitamin and dietary mineral), food and energy. Table 1 show results of micronutrient (vitamin and dietary mineral), food and energy intakes.

The mean value for food intake of rural women was 799 g/day and an adequate intake of mean energy i.e. 2191 $\mathrm{k} . \mathrm{cal} /$ day was observed which was as per recommendations daily allowance (RDA). An inadequate intake of dietary mineral and a lower utilization of calcium in comparison to recommended daily allowance (RDA) was observed in rural women. A mean intake of $507 \mathrm{mg} /$ day of calcium by the rural women showed that it was $50 \%$ below the recommended daily allowance (RDA). An adequate intake of phosphorus, which was $809 \mathrm{mg} /$ day on average, was noted among the rural women as compared to the agespecific suggestion with the assumption of $800 \mathrm{mg} /$ day diet.

A similar intake of iron consumption amounting up to $27.6 \mathrm{mg} /$ day was somewhat higher than RDA, whereas the intake of zinc which was $11.5 \mathrm{mg} /$ day on the average was found inadequate in rural women in comparison to recommended daily allowance (RDA). A similar trend in intake of iodine was observed.

Table 1 shows that vitamins intake of rural women and it is evident that the intake of the vitamin was not adequate. Among most of the rural women, a lower utilization of vitamin-C and vitamin-A was noted in comparison to recommended daily allowance (RDA). A 50\% below the recommended daily allowance (RDA) of vitamin-C and vitamin-A intakes were observed amounting up to 21.1 $\mathrm{mg} /$ day and 126 R.E/day. The intake of Niacin was not adequate in comparison to recommended daily allowance (RDA) amounting up to $2.79 \mathrm{mg} /$ day. The same trend was noted in the intakes of riboflavin and thiamine which were very low in the rural women. The mean values of riboflavin and thiamine intakes were 0.28 and $0.30 \mathrm{mg} /$ day respectively.

\section{Pir Sabaq}

Daily intake of nutrients of fifty (50) rural women was calculated and the 24-hour memory recall questionnaire method was used for the investigation. The calculation of daily micronutrient, energy, and the food was done, and the 
results are shown in Table 2. The mean of food intakes of rural women was found to be $831 \mathrm{~g} /$ women/day while the mean intake of energy was $2178 \mathrm{~K}$. Calories/women/day which was adequate as per the recommendations.

As a whole, inadequate intake of micronutrients in the rural women was observed and a lower utilization of calcium, in comparison to recommended daily allowance
(RDA), was noted in the majority of rural women. A 50\% below the recommended daily allowance (RDA) amounting up to $543 \mathrm{mg} /$ woman/day intake of calcium was observed in rural women. Similarly, the mean intake of phosphorus, which was $766 \mathrm{mg} /$ woman/day, was also not adequate in accordance with the age-specific suggestions namely 800 $\mathrm{mg} / \mathrm{day}$.

Table 1. Daily food, energy, dietary mineral intake and daily vitamin intake of women in Village Akora Khattak, District of Nowshera, Khyber Pakhtunkhwa, Pakistan

\begin{tabular}{|c|c|c|c|c|c|c|c|c|c|c|c|c|c|c|}
\hline & $\begin{array}{c}\text { Food } \\
\text { intake } \\
(\mathrm{g})\end{array}$ & $\begin{array}{c}\text { Food } \\
\text { energy } \\
\text { (k.cal) }\end{array}$ & $\begin{array}{c}\text { Ash } \\
\text { (g) }\end{array}$ & $\begin{array}{c}\text { Calcium } \\
\text { (mg) }\end{array}$ & $\begin{array}{l}\text { Phosphorus } \\
\text { (mg) }\end{array}$ & $\begin{array}{l}\text { Iron } \\
\text { (mg) }\end{array}$ & $\begin{array}{l}\text { Zinc } \\
\text { (mg) }\end{array}$ & $\begin{array}{l}\text { Iodine } \\
\text { (ppm) }\end{array}$ & $\begin{array}{l}\text { Thiamine } \\
\text { (B1)(mg) }\end{array}$ & $\begin{array}{c}\text { Riboflavin } \\
\text { (B2)(mg) }\end{array}$ & $\begin{array}{c}\text { Niacin } \\
\text { (B3) } \\
\text { (mg) }\end{array}$ & $\begin{array}{c}\text { Vitamin- } \\
\text { C (mg) }\end{array}$ & $\begin{array}{c}\beta- \\
\text { Carotene } \\
\text { (mcg) }\end{array}$ & $\begin{array}{c}\text { Vitamin- } \\
\text { A (R.E) }\end{array}$ \\
\hline Mean* & 799 & 2191 & 10.18 & 507 & 809 & 27.60 & 11.52 & 7.69 & 0.28 & 0.30 & 2.79 & 21.17 & 138 & 126 \\
\hline Median & 827 & 2225 & 11.00 & 503 & 810 & 28 & 12 & 3 & 0.25 & 0.31 & 3 & 18 & 117 & 73 \\
\hline Min. & 543 & 1485 & 5.65 & 258 & 410 & 14.00 & 6.54 & 0.13 & 0.09 & 0.08 & 0.85 & 0.93 & 22 & 28 \\
\hline Max. & 998 & 2866 & 12.96 & 714 & 1266 & 36.33 & 15.26 & 47.97 & 0.69 & 0.58 & 6.20 & 56.43 & 482 & 879 \\
\hline SD & 115.0 & 306 & 1.60 & 102.5 & 199.6 & 4.9 & 1.8 & 11.4 & 0.1 & 0.1 & 1.2 & 14.7 & 91.5 & 156.2 \\
\hline CV\% & 14.40 & 13.96 & 15.83 & 20.23 & 24.67 & 17.78 & 15.94 & 148.67 & 46.98 & 37.14 & 44.11 & 69.45 & 66.34 & 123.71 \\
\hline
\end{tabular}

Note: $*=$ Values are means of 50 rural women randomly selected in a village

Table 2. Daily food, energy, dietary mineral intake and daily vitamin intake of women in Village Pir Sabaq, District of Nowshera, Khyber Pakhtunkhwa, Pakistan

\begin{tabular}{|c|c|c|c|c|c|c|c|c|c|c|c|c|c|c|}
\hline & $\begin{array}{l}\text { Food } \\
\text { intake } \\
(\mathrm{g})\end{array}$ & $\begin{array}{c}\text { Food } \\
\text { energy } \\
\text { (k.cal) }\end{array}$ & $\begin{array}{c}\text { Ash } \\
\text { (g) }\end{array}$ & $\begin{array}{c}\text { Calcium } \\
(\mathrm{mg})\end{array}$ & $\begin{array}{c}\text { Phosphorus } \\
\text { (mg) }\end{array}$ & $\begin{array}{l}\text { Iron } \\
(\mathrm{mg})\end{array}$ & $\begin{array}{l}\text { Zinc } \\
(\mathrm{mg})\end{array}$ & $\begin{array}{l}\text { Iodine } \\
\text { (ppm) }\end{array}$ & $\begin{array}{l}\text { Thiamine } \\
\text { (B1)(mg) }\end{array}$ & $\begin{array}{c}\text { Riboflavin } \\
\text { (B2)(mg) }\end{array}$ & $\begin{array}{l}\text { Niacin } \\
\text { (B3) } \\
\text { (mg) }\end{array}$ & $\begin{array}{c}\text { Vitamin- } \\
\text { C (mg) }\end{array}$ & $\begin{array}{c}\beta- \\
\text { Carotene } \\
(\mathbf{m c g})\end{array}$ & $\begin{array}{c}\text { Vitamin- } \\
\text { A (R.E) }\end{array}$ \\
\hline Mean* & 831 & 2178 & 10.32 & 543 & 766 & 28.43 & 11.51 & 5.28 & 0.33 & 0.35 & 2.74 & 24.12 & 622 & 297 \\
\hline Median & 808 & 2179 & 10 & 529 & 781 & 28 & 12 & 4 & 0 & 0 & 3 & 22 & 296 & 280 \\
\hline Min. & 690 & 1594 & 6.51 & 343 & 419 & 15.22 & 7.54 & 0.40 & 0.15 & 0.13 & 0.78 & 5.07 & 55 & 24 \\
\hline Max. & 1048 & 2644 & 13.06 & 910 & 1083 & 37.47 & 14.90 & 43.53 & 1.11 & 0.70 & 5.80 & 75.30 & 4684 & 859 \\
\hline SD & 81.1 & 196.0 & 1.1 & 115.0 & 199.1 & 4.2 & 1.5 & 7.2 & 0.2 & 0.2 & 1.2 & 15.2 & 946.9 & 195.3 \\
\hline CV\% & 10 & 9 & 11 & 21 & 26 & 15 & 13 & 136 & 53 & 44 & 46 & 63 & 152 & 66 \\
\hline
\end{tabular}

Note: $*=$ Values are means of 50 rural women randomly selected in a village

Table 3. Daily food, energy, dietary mineral intake and daily vitamin intake of women in Village Kheshki, District of Nowshera, Khyber Pakhtunkhwa, Pakistan

\begin{tabular}{|c|c|c|c|c|c|c|c|c|c|c|c|c|c|c|}
\hline & $\begin{array}{l}\text { Food } \\
\text { intake } \\
(\mathrm{g})\end{array}$ & $\begin{array}{c}\text { Food } \\
\text { energy } \\
\text { (k.cal) }\end{array}$ & $\begin{array}{c}\text { Ash } \\
\text { (g) }\end{array}$ & $\begin{array}{c}\text { Calcium } \\
\text { (mg) }\end{array}$ & $\begin{array}{c}\text { Phosphorus } \\
\text { (mg) }\end{array}$ & $\begin{array}{l}\text { Iron } \\
\text { (mg) }\end{array}$ & $\begin{array}{l}\text { Zinc } \\
(\mathrm{mg})\end{array}$ & $\begin{array}{l}\text { Iodine } \\
\text { (ppm) }\end{array}$ & $\begin{array}{l}\text { Thiamine } \\
\text { (B1)(mg) }\end{array}$ & $\begin{array}{c}\text { Riboflavin } \\
\text { (B2)(mg) }\end{array}$ & $\begin{array}{c}\text { Niacin } \\
\text { (B3) } \\
\text { (mg) }\end{array}$ & $\begin{array}{c}\text { Vitamin- } \\
\text { C (mg) }\end{array}$ & $\begin{array}{c}\beta- \\
\text { Carotene } \\
\text { (mcg) }\end{array}$ & $\begin{array}{l}\text { Vitamin- } \\
\text { A (R.E) }\end{array}$ \\
\hline Mean* & 811 & 2122 & 10.04 & 519 & 742 & 27.82 & 11.11 & 5.82 & 0.33 & 0.32 & 2.84 & 18.19 & 164 & 93 \\
\hline Median & 798 & 2110 & 10 & 500 & 725 & 27 & 11 & 3 & 0 & 0 & 3 & 16 & 135 & 51 \\
\hline Min. & 652 & 1705 & 7.77 & 349 & 396 & 20.52 & 8.22 & 0.40 & 0.12 & 0.08 & 0.64 & 2.67 & 36 & 5 \\
\hline Max. & 1047 & 2681 & 13.15 & 858 & 1188 & 36.82 & 14.65 & 41.50 & 0.56 & 0.65 & 6.47 & 53.87 & 486 & 364 \\
\hline SD & 74.5 & 219.4 & 1.2 & 104.2 & 183.6 & 3.6 & 1.7 & 8.2 & 0.1 & 0.1 & 1.3 & 10.8 & 118.2 & 83.1 \\
\hline CV\% & 9 & 10 & 12 & 20 & 25 & 13 & 15 & 141 & 35 & 41 & 47 & 59 & 72 & 89 \\
\hline
\end{tabular}

Note: *= Values are means of 50 rural women randomly selected in a village

Table 4. Daily food, energy, dietary mineral intake and daily vitamin intake of women in District of Nowshera, Khyber Pakhtunkhwa, Pakistan

\begin{tabular}{|c|c|c|c|c|c|c|c|c|c|c|c|c|c|c|}
\hline & $\begin{array}{c}\text { Food } \\
\text { intake } \\
(\mathrm{g})\end{array}$ & $\begin{array}{c}\text { Food } \\
\text { energy } \\
\text { (k.cal) }\end{array}$ & $\begin{array}{c}\text { Ash } \\
\text { (g) }\end{array}$ & $\begin{array}{l}\text { Calcium } \\
(\mathrm{mg})\end{array}$ & $\begin{array}{c}\text { Phosphorus } \\
\text { (mg) }\end{array}$ & $\begin{array}{l}\text { Iron } \\
(\mathrm{mg})\end{array}$ & $\begin{array}{l}\text { Zinc } \\
(\mathrm{mg})\end{array}$ & $\begin{array}{l}\text { Iodine } \\
\text { (ppm) }\end{array}$ & $\begin{array}{l}\text { Thiamine } \\
\text { (B1)(mg) }\end{array}$ & $\begin{array}{c}\text { Riboflavin } \\
\text { (B2)(mg) }\end{array}$ & $\begin{array}{l}\text { Niacin } \\
\text { (B3) } \\
\text { (mg) }\end{array}$ & $\begin{array}{l}\text { Vitamin- } \\
\text { C (mg) }\end{array}$ & $\begin{array}{c}\beta- \\
\text { Carotene } \\
(\mathrm{mcg})\end{array}$ & $\begin{array}{l}\text { Vitamin- } \\
\text { A (R.E) }\end{array}$ \\
\hline Mean* & 814 & 2164 & 10.18 & 523 & 773 & 28 & 11 & 6.61 & 0.31 & 0.32 & 2.79 & 21 & 201 & 172 \\
\hline Median & 808 & 2174 & 10.29 & 511 & 777 & 28 & 11 & 2.85 & 0.30 & 0.31 & 2.72 & 18 & 167 & 103 \\
\hline Min. & 543 & 1485 & 5.65 & 258 & 396 & 14 & 6.5 & 0.13 & 0.09 & 0.08 & 0.64 & 0.93 & 22 & 5 \\
\hline Max. & 1048 & 2866 & 13.15 & 910 & 1266 & 37 & 15 & 48 & 1.11 & 0.70 & 6.5 & 75 & 867 & 879 \\
\hline SD & 92.3 & 245.2 & 1.33 & 107.7 & 194.9 & 4.3 & 1.68 & 9.1 & 0.14 & 0.13 & 1.3 & 13.8 & 149.9 & 175.7 \\
\hline CV\% & 0.113 & 0.113 & 0.131 & 0.206 & 0.252 & 0.153 & 0.147 & 1.383 & 0.456 & 0.413 & 0.451 & 0.654 & 0.747 & 1.021 \\
\hline
\end{tabular}

Note: *= Values are means of 50 rural women randomly selected in a village 
A similar intake of iron consumption amounting up to $28.4 \mathrm{mg} /$ day was somewhat higher whereas the intake of zinc which was $11.5 \mathrm{mg} /$ day on the average, was found inadequate in rural women in accordance to recommended daily allowance (RDA). A similar trend in intake of Iodine, which amounted up to $5.2 \mathrm{mg} /$ woman/day, was observed.

Table 3 shows vitamins intake of rural women and itshows that the intake of the vitamin was not adequate. Among most of the rural women, a lower utilization of vitamin-C and vitamin-A was noted in comparison to recommended daily allowance (RDA). A 50\% below the recommended daily allowance (RDA) of vitamin-C and vitamin-A intakes were observed amounting up to 24.1 mg/day and 297 R.E/day.

The intake of Niacin was not adequate in comparison to recommended daily allowance (RDA) amounting up to $2.74 \mathrm{mg} /$ day. The same trend was noted in the intakes of riboflavin and thiamine which were very low in the rural women. The mean values of riboflavin and thiamine intakes were 0.35 and $0.33 \mathrm{mg} /$ day respectively.

\section{Kheshki}

Daily intake of nutrients of fifty (50) rural women was calculated and the 24-hour memory recall questionnaire method was used for the investigation. The calculation of daily micronutrient, energy, and food was done, and the results were shown in Table 3 . The mean of food intakes of rural women was found to be $811 \mathrm{~g} /$ women/day while the mean intake of energy was 2122 k.calories/women/day which was adequate as per the recommendations

As a whole, inadequate intake of micronutrients in the rural women was observed and a lower utilization of calcium, in comparison to recommended daily allowance (RDA), was noted in the majority of rural women. A 50\% below the recommended daily allowance (RDA) amounting up to $519 \mathrm{mg} /$ woman/day intake of calcium was observed in rural women. Similarly, the mean intake of phosphorus, which was $742 \mathrm{mg} /$ woman/day, was also not adequate in contrast to the age-specific suggestions namely 800 $\mathrm{mg} /$ day.

A similar intake of iron consumption amounting up to $28.8 \mathrm{mg} /$ day was somewhat higher whereas the intake of zinc which was $11.1 \mathrm{mg} /$ day on the average was found inadequate in rural women in comparison to recommended daily allowance (RDA). A similar trend in intake of Iodine, which amounted up to $5.82 \mathrm{mg} /$ woman/day, was observed.

Table 3 shows vitamins intake of rural women and it is evident that the intake of the vitamin was not adequate. Among most of the rural women, a lower utilization of vitamin-C and vitamin-A was noted in comparison to recommended daily allowance (RDA). A 50\% below the recommended daily allowance (RDA) vitamin-C and vitamin-A intakes were observed amounting up to 18 $\mathrm{mg} /$ day and $93 \mathrm{R} . \mathrm{E} /$ day respectively.

The intake of Niacin was not adequate in comparison to recommended daily allowance (RDA) amounting up to $2.84 \mathrm{mg} /$ day. The same trend was noted in the intakes of riboflavin and thiamine which were very low in the rural women. The mean values of riboflavin and thiamine intakes were 0.32 and $0.33 \mathrm{mg} /$ day respectively.

\section{District of Nowshera (Average of all 3 localities)}

Daily intake of nutrients of one hundred and fifty (150) rural women was calculated and the 24-hour memory recall questionnaire method was used for the investigation. Ater the calculation of daily micronutrient, energy, and the food was done, the results are shown in Table 4. The mean of food intakes of rural women was found to be 814 g/women/day while the mean intake of energy was 2164 k.calories/women/day which was adequate as per the recommendations

As a whole, inadequate intake of micronutrients in the rural women was observed and a lower utilization of calcium, in comparison to recommended daily allowance (RDA), was noted in the majority of rural women. A 50\% below the recommended daily allowance (RDA) amounting up to $523 \mathrm{mg} /$ woman/day intake of calcium was observed in rural women. Similarly, the mean intake of phosphorus, which was $773 \mathrm{mg} /$ woman/day, was also not adequate in contrast to the age-specific suggestions namely 800 $\mathrm{mg} /$ day. A similar intake of iron consumption amounting up to $28 \mathrm{mg}$ /day was observed, which was somewhat higher than RDA, whereas the intake of zinc which was 11 $\mathrm{mg} /$ day on the average, was found inadequate in rural women in comparison to recommended daily allowance (RDA). A similar trend in intake of Iodine, which amounted up to $6.61 \mathrm{mg} /$ woman/day, was observed.

Table 4 shows vitamins intake of rural women and it is evident that the intake of the vitamin was not adequate. Among most of the rural women, a lower utilization of vitamin-C and vitamin-A was noted in comparison to recommended daily allowance (RDA). A 50\% below the recommended daily allowance (RDA) vitamin-C and vitamin-A intakes were observed amounting up to 21 $\mathrm{mg} /$ day and 172R.E/day respectively. The intake of Niacin was not adequate in comparison to recommended daily allowance (RDA) amounting up to $2.79 \mathrm{mg} /$ day. The same trend was noted in the intakes of riboflavin and thiamine which were very low in the rural women. The mean values of riboflavin and thiamine intakes were 0.32 and 0.31 mg/day respectively.

\section{Anthropometry of women \\ Akora Khattak}

This study was aimed to relate the data obtained through 24-hour memory recall questionnaire to the requirement of energy through basal metabolic rates (BMR) calculations. The rural women's weight and height were inquired and calculation of Basal Metabolic Rate (BMR) was done. Estimation of nutritional status of rural women was done and Basal Metabolic Rate (BMR) was calculated using the standard formula BMI=weight (kg)/height (m2). The Basal Metabolic Rate (BMR) was calculated as per World Health Organization (WHO) (FAO/WHO/UNU 1985) guidelines which lead us to the nutritional status of the rural women. The references for different basal metabolic rate (BMI) class which were as: BMI < 18.5 were underweight for chronic energy deficiency; 18.5-24.9 for normal; 25.0-29.9 for overweight; 30 for obese. 
The weight of rural women in Akora Khattak ranged from $41-81 \mathrm{~kg}$ where the mean weight was $65.5 \mathrm{~kg}$ and the height ranged from $1.14-1.71 \mathrm{~m}$ where the mean was $1.52 \mathrm{~m}$. Similarly, their basal metabolic rate (BMI) ranged from 20.0 to 52.0 bringing the mean of 29.06. It is evident from the results that the BMI of almost all the rural women in Akora Khattak is greater than 18.5. Table 5 shows result of the study which shows that out of the 50 rural women in Akora Khattak, not even a single women was found as underweight whereas the woman in normal category was $28 \%$, in the overweight category was $36 \%$ and in the obesity category was $36 \%$.

\section{Pir Sabaq}

The weight of rural women in Pir sabaq ranged from $43-79 \mathrm{~kg}$ and the mean of weight was $65.27 \mathrm{~kg}$ while the height ranged from $1.26-1.72 \mathrm{~m}$ and the mean of height was $1.54 \mathrm{~m}$. Similarly, their basal metabolic rate (BMI) ranged from 20.0 to 42.0 bringing the mean to 28.07 . It is evident from the results that the BMI of almost all the rural women in Pir sabaq is greater than 18.5. Table 5 shows result of the study informing that out of the 50 rural women in Pir sabaq, not even a single women was found as underweight whereas the woman in normal category was $30 \%$, in the overweight category was $40 \%$ and in the obesity category was $30 \%$.

Table 5. Anthropometry of women in villages of Akora Khattak, Pir Sabaq and Kheshki, as well as District of Nowshera, Khyber Pakhtunkhwa, Pakistan

\begin{tabular}{|c|c|c|c|}
\hline & Height $\left(\mathbf{m}^{2}\right)$ & Weight (Kg) & BMI $\left(\mathrm{Kg} / \mathrm{m}^{2}\right)$ \\
\hline \multicolumn{4}{|c|}{ Village Akora Khattak } \\
\hline Mean* & 2.32 & 65.51 & 29.06 \\
\hline Median & 2.42 & 65 & 28 \\
\hline Min. & 1.31 & 41 & 20 \\
\hline Max. & 2.94 & 81 & 52 \\
\hline SD & 0.437 & 9.2 & 6.1 \\
\hline $\mathrm{CV} \%$ & 0.189 & 0.140 & 0.208 \\
\hline \multicolumn{4}{|c|}{ Village Pir Sabaq } \\
\hline Mean* & 2.37 & 65.27 & 28.07 \\
\hline Median & 2.43 & 65 & 28 \\
\hline Min & 1.59 & 43 & 20 \\
\hline $\operatorname{Max}$ & 2.96 & 79 & 42 \\
\hline Sd & 0.366 & 8.6 & 4.7 \\
\hline CV\% & 0.155 & 0.132 & 0.168 \\
\hline \multicolumn{4}{|c|}{ Village Kheshki } \\
\hline Mean* & 2.34 & 65.18 & 28 \\
\hline Median & 2.42 & 65 & 28.1 \\
\hline Min & 1.42 & 41 & 19.62 \\
\hline Max & 2.89 & 79 & 46.62 \\
\hline Sd & 0.390 & 8.8 & 5.0 \\
\hline CV\% & 0.167 & 0.134 & 0.177 \\
\hline \multicolumn{4}{|c|}{ District of Nowshera (sum of above three villages) } \\
\hline Mean & 2.34 & 65.32 & 28.54 \\
\hline Median & 2.42 & 65 & 28.07 \\
\hline Min & 1.31 & 41 & 19.62 \\
\hline Max & 2.96 & 81 & 52.27 \\
\hline Sd & 0.40 & 8.79 & 5.28 \\
\hline $\mathrm{CV} \%$ & 0.17 & 0.13 & 0.19 \\
\hline
\end{tabular}

Note: $*=$ Values are means of 50 respondents randomly selected in a locality.

\section{Kheshki}

The weight of rural women in Kheshki ranged from 41$79 \mathrm{~kg}$ and the mean weight was $65.18 \mathrm{~kg}$ and the height ranged from $1.19-1.70 \mathrm{~m}$ and the mean was $1.52 \mathrm{~m}$. Similarly, their basal metabolic rate (BMI) ranged from 19.6 to 46.6 with the mean of 28.00. It is evident from the results that the BMI of almost all the rural women in Kheshki is greater than 18.5. Table 5 shows result of the study informing that out of the 50 rural women in Kheshki, not even a single women was found as underweight whereas the woman in normal category was 32\%, in the overweight category was $30 \%$ and in the obesity category was $38 \%$.

\section{District of Nowshera (Average of all 3 localities)}

The basal metabolic rate (BMR) of rural women in District of Nowshera ranged from 19.6 to 52.2 bringing the mean to 28.54. It is evident from the results that the BMI of almost all the rural women in District of Nowshera is greater than 18.5. Table 5 shows result of the study informing that out of one hundred and fifty (150) rural women in District of Nowshera, not even a single women was found in underweight condition, whereas $30 \%$ of them was in the normal category, $35.3 \%$ of them was in the overweight category and $34.7 \%$ of them was in the obesity category. The weight of rural women in District of Nowshera ranged from 41-81 kg and the mean weight was $65.32 \mathrm{~kg}$ and the height ranged from 1.14-1.72 $\mathrm{m}$ and the mean was $1.52 \mathrm{~m}$.

\section{Discussion}

This study aimed for determination of the nutritional status of the rural women and estimation of intake of micronutrient, food and energy of Pakistani rural women. Considerations in relation to the selection of target group of population, selection of volunteer, food selection awareness along with its relation to nutritional status are very imperative. The intake levels of micronutrient on rural women in target area were estimated with the help of the 24-hour memory recall questionnaire method.

\section{Nutritional status}

Weight and height were used to determine the nutritional status through BMI where the results showed the nearly same mean of heights and weights of the rural women from the three villages of Nowshera leading to correspondingly same mean values of BMI in all the villages. The average BMI was higher than normal and a significantly high BMI in women was observed in studies conducted by Chowdhury (1985) and Torres et al. (1990). Approximately similar status of nutrition of women was reported in similar studies.

It was also evident in another study reported by Ahmed (1999), which gave values of anthropometry for women groups. The study targeted women with more land ownership while the second group was women owing less land. The study revealed that women from the households with the land of more than half an acre erewere found to be significantly weightier than the women having less land. Their heights were, however, reported as the same. The 
values for weight and height of rural women were exactly similar to those reported by Ahmed (1999). Nearly same, values of BMI of the rural women in District of Nowshera, in general, were found in line with their socio-economic conditions, which are clearly suggesting that the average value of the basal metabolic index (BMI) is the attribute of their high intake of food.

When the basal metabolic index (BMI) reference values regarding underweight, normal, overweight and obese category were compared with these results, it was evident that obesity prevailed in most of the rural women of Nowshera which further lead to the increased risk of obesity-related disorders and mortality chances. As reported, very little chances the above problems occur in people having a basal metabolic index (BMI) in the normal range. As per World Health Organization (WHO 2005) reports, diabetes, heart disease, osteoarthritis, breast, endometrial and colon cancers are all the dangers which can be associated with increased weight and obese people. It can, therefore, be summarized that women with normal weight are much safer from these nutritional problems than those having higher weight or overweight. Tajik women have been found to be having more load of nutritional problems due to WHO (2000) high basal metabolic index (BMI) plus high blood pressure clearly indicating the relation of overweight/obese with heart diseases.

\section{Energy intake}

Energy intake on the average for the three localities of the selected district was $2191 \mathrm{k} . c a l / w o m a n /$ day in Akora Khattak, 2178 kcal/women/day in Pir Sabaq, and 2122 $\mathrm{kcal} /$ women/day in Kheshki (data analysis is not shown). The values show only marginal adequacy on the basis of BMR relative to height, acceptable median weight for height. Although it has been suggested that BMR for women in the indo-Pak subcontinent might be lower than the normal reported values (Piers and Shetty 1993), these, however, have not been substantiated with objective evidence and hence FAO/WHO/UNU (1985) suggestions were adopted for calculating BMR values.

One of the primary problems of malnutrition is obesity. Its prevention requires a balance of energy intake and energy output. When the energy intake is less than 1800 to $2000 \mathrm{Kcal}$, it is difficult to include all nutrients at recommended levels, especially for some of the trace elements. Thus it is more appropriate to increase exercise than to decrease energy intake into below $2000 \mathrm{kcal}$ if the goal is weight maintenance.

For those who are obese, low calories diets ranging from 1000 to $1800 \mathrm{kcal}$ are used. Between 70 and $80 \%$ of the women's energy intake was supplied by bread from the food group of “cereals and grain products”.

\section{Dietary mineral intake}

Calcium intake. The average of calcium intake of the women in the volunteer groups belonging to the three selected locations in District of Nowshera was on significantly lower than the RDA. The mean calcium intake was $523 \mathrm{mg} /$ woman/day (Table 4) which was 36\% lesser than the recommended intake level. The recommended allowance for calcium is $800 \mathrm{mg} /$ day. Although intake of various food groups by the target population group was not recorded, the low calcium intake by the volunteers indicated a low intake of milk and its products in the daily diet. Worsening the situation with respect to intake of calcium and other minerals was the fact that wheat and pulses, as major parts of the diet, contain very high concentrations of phytates. It is well documented (Allen and Wood 1994) that phytates bind most of the mineral matter present in the diet, making it physiologically unavailable to the consuming individual, leading to a deficiency of the mineral in question.

Phosphorus intake. The average daily intake of phosphorus (mg/d) among the volunteer women was much lower than the RDA as calculated by $24 \mathrm{hr}$ memory recall questionnaire method. The women had a mean phosphorus intake of $773 \mathrm{mg} /$ woman/day (Table 4) which was less than the recommended level. The recommended allowance for phosphorus is $800 \mathrm{mg} /$ day (data analysis is not shown). The results showed that mean phosphorus intake of women in Akora Khattak was significantly higher than RDA which was $809 \mathrm{mg}$ (Table 1) while in Pir Sabaq and Kheshki, the mean phosphorus intake of women was $766 \mathrm{mg}$ (Table 2), $742 \mathrm{mg} /$ day (Table 3) respectively which were not significantly higher than RDA. Phosphorus along with calcium is essential for the formation of bones and teeth. It is also involved in the storage of energy and its release in the body. Diets that provide adequate energy and protein also supply adequate phosphorus. So the foods that are rich in protein are good sources of phosphorus.

Iron intake. The mean iron intakes were 28 $\mathrm{mg} /$ day/women with a range of intake of 14 to $37 \mathrm{mg}$ (data analysis is not shown). The values showed a satisfactory dietary intake level of that mineral as seen in comparison with the RDA (FAO/WHO 1988). However since a predominant part of the diet in the rural population was cereals and pulses, the bioavailability of minerals, including iron, was very low. It has been reported that iron bioavailability from such diet sources might not be higher than 5\% (Siegenberg et al. 1991). Iron intake level is critical particularly in child-bearing women due to their unique function of reproduction. It is therefore important to keep the iron nutritional status of these women within safe limits (Abuova 1996).

Zinc intake. Daily zinc consumption (mg/d) was not significantly higher than the RDA in all women as calculated by $24 \mathrm{hr}$ memory recall questionnaire method. The women had a mean zinc intake $11 \mathrm{mg} /$ woman/day (Table 9) which were above the recommended level. The recommended allowance for zinc is $15 \mathrm{mg} /$ day (data analysis is not shown). The results showed that calculated mean zinc intake of women of Akor Khattak, Pir Sabaq and Kheshki were significantly lower than RDA which was $11.52 \mathrm{mg} /$ day (Table 1), $11.51 \mathrm{mg} /$ day (Table 2), and 11.11 mg/day (Table 3) respectively. As it was clearly portrayed from the diet consumed by the women, that more than enough calories were furnished by whole-grains bread. Although whole-grains are good sources of zinc, practically all of the minerals are tied up by the high concentration of phytates in the unleavened bread. Due to its involvement in 
the immune system, zinc is considered as a very important nutrient. A deficiency of it may lead to vulnerability to several pathogens and their adverse effects (Fraker et al. 1986; Kruse-Jarres 1989). Zinc deficiency is considered to be emerging in Pakistan. This is attributed to a great extent to the exhaustion of the soils due to intensive cultivation systems. Food fortification with zinc compounds is considered to be one of the most promising options to overcome the ill effects of zinc deficiency among the population (World Bank 1994).

The discussions in the preceding sections of this manuscript provide the basis for the conclusion of this study. (i) Nutritional status of women was done by using data on height and weight measurements. BMI value of 18.5 to 24.9 indicated the healthy weight of 18.5 as underweight, of above 25 as overweight and of above 30 as obese. When BMI of women was compared with these categories; it showed that quite large proportion of the women were overweight and obese. (ii) The women's energy intakes were marginally adequate as they were almost equal to the recommendations. (iii) Among the minerals, calcium, phosphorus, and zinc were much less than the recommended daily intakes

\section{ACKNOWLEDGEMENTS}

The cooperation and help extended by the following teachers and colleagues are acknowledged: Dr. Farhatullah, Dr. Ihsanullah, Dr. Mirza Habib Ali, and Nematullah. The following institutes are acknowledged for using their facilities and laboratories: Department of Human Nutrition, University of Agriculture, Peshawar, Pakistan, Nuclear Institute for Food and Agriculture, Peshawar, Pakistan, Natural Sciences Linkage Program, Pakistan Science Foundation, Islamabad, Pakistan.

\section{REFERENCES}

Abuova G. 1996. Multi-ethnic Study of the Nutritional Status of the General Population in the Republic of Kazakstan. National Institute of Nutrition of the Republic of Kazakstan, Almaty. [Kazakstan]

Ahmed A. 1999. In the Food For education Program in Bangladesh, Out of the Shadow of Famine, Evolving Food Policy in Bangladesh, Johns Hopkins University Press, Baltimore, USA

Allen LN, Wood RJ. 1994. Calcium and phosphorus. In: Shils ME, Olson JA, Shike M (eds.). Modern Nutrition in Health and Disease. 8th ed., Lea \& Febiger, Philadelphia, USA.
Arellano M, Garcia-Caselles, M.P, Pi-Figueras, M, Miralles, R, Torres, R.M, Agui- lera, A, Cervera A.M. 2004. Clinical, impact on different scores of the mini nutritional assessment (MNA) in the diagnosis of malnutrition in patients with cognitive impairment, Archives of Gerontology and Geriatrics, Supplement-9, pp. 27-31,

Chowdhury A.A.K.M. 1985. Changes in maternal nutritional status in a chronically malnourished population in rural Bangladesh, J Ecol Food Nutr 19: 201-211.

FAO/WHO. 1988. Requirements of vitamin A, iron, folate and vitamin B12. Report of Joint FAO/WHO Expert Consultation. 107 Seiten, 5 Abb., 24 Tab. Food and Agriculture Organization of the United Nations, Rome.

FAO/WHO/UNU. 1985. Energy and protein requirements, Report of a joint FAO/WHO expert consultation. World Health Organisation Technical Report Series, 724, Food and Agriculture Organization of the United Nations, Rome.

Fraker PJ, Gershwin ME, Good RA, Prasad A.1986. Interrelationships between zinc and immune function. Fed Proc 45 (5): 1474-1479.

Kruse-Jarres JD. 1989. The significance of zinc for humoral and cellular immunity. J Trace Elements Electrolytes Health Dis 3: 1-8

Martorell R, Ramakrishnan U, Schroeder D.G, Melgar P and Neufeld L. 1998. Intrauterine growth retardation, body size, body composition and physical performance in adolescence. Eur J Clin Nutr 52: S43-53

Peel N.M, Mcclure R.J, Bartlett H.P. 2005. Behavioral determinants of healthy aging. Amer J Preven Med 28: 298-304.

Piers L.S, Shetty P.S. 1993. Basal metabolic rates of Indian women, Eur J Clin Nutr 47: 586-591.

Pirlich M, Lochs H. 2001. Nutrition in the elderly, Best Practices and Research. Clinical Gastroenterol 15: 869-884.

Rouse DJ. 2003. Potential Cost-Effectiveness of Nutrition Interventions to Prevent Adverse Pregnancy Outcomes in the Developing World. J Nutr 133: 1640S-1644S.

Ruiz-Lopez MD, Artacho R, Oliva P, Moreno-Torres R, Bolanos J, De Teresa C, Lopez C. 2003. Nutritional risk in Institutionalized older women determined by the Mini Nutritional Assessment Test: what are the main Factors? Nutrition 19 (9): 767-771,

Siegenberg D, Baynes RD, Bothwell TH, Macfarlane BJ, Lamparelli RD, Car NG, MacPhail P, Schmidt U, Tal A, Mayet F. 1991. Ascorbic acid prevents the dose-dependent inhibitory effects of polyphenols and phytates on nonheme-iron absorption. Am J Clin Nutr 53 (2): 537-541.

Tabak AG, Tamas G, Zgibo J, Wilson R, Becker D, Kerenyi Z, Orchard TJ. 2000. Targets and reality: a comparison of health care indicators in the US (Pittsburgh EDC Study) and in Hungary (DiabCare hungary). Diabetes Care 23: 1284-1289.

Torres A, Willett W, Orav J, Chen L, Huq E. 1990. Variability of total energy and protein intake in rural Bangladesh: Implications for epidemiological studies of diet in developing countries. Food Nutr Bull 12 (3): 220-228.

World Bank. 1994. Enriching Lives: Overcoming Vitamin and Mineral Malnutrition in Developing Countries (Development in Practice). World Bank, Policy Research Department, Washington, D.C.

World Health Organization [WHO]. 2000. The Asia-Pacific Perspective: Redefining Obesity and its Treatment, International Association for the Study of Obesity (IASO), Western Pacific Region, Health Communications Australia, Sydney.

World Health Organization [WHO]. 2005. Highlights on health in Tajikistan. World Health Organization, Geneva. 